\title{
Orangzab,
}

Ph.D., COMSATS University Islamabad, Pakistan

iD ORCID ID, 0000-0002-0010-7655

email: orangzab@ciitvehari.edu.pk

Muhammad Sajjad,

Ph.D., COMSATS University Islamabad, Pakistan

(iD) ORCID ID, 0000-0001-8409-0063

email:goesajjad@gmail.com

Muhammad Umair Zulfiqar,

COMSATS University Islamabad, Pakistan

(iD) ORCID ID, 0000-0002-3249-5293

email: umairzulfiqar94@gmail.com

Muhammad Irfan Chani,

Ph.D., COMSATS University Islamabad, Pakistan

D ORCID ID, 0000-0002-5728-8215

email: irfanchani@ciitvehari.edu.pk

Bilal Tariq,

Ph.D., COMSATS University Islamabad, Pakistan

iD ORCID ID, 0000-0003-0800-3559

email: bilaltariq@ciitvehari.edu.pk

Rai Imtiaz Hussain,

University of OKARA, Pakistan

(iD) ORCID ID, 0000-0003-0532-7849

email: rai.hussain@uo.edu.pk

Correspondence author: goesajjad@gmail.com

\section{INFLUENTIAL FACTORS OF BRAND EXTENSION AMONG UNIVERSITY STUDENTS: CASE FOR PAKISTAN}

Abstract. Brand extension is considered to be a highly plausible and essential factor for the success of new products. It is an elusive concept that adds value to the offered products and gives a competitive advantage for strategical positioning of new products in the consumers' minds. This study carefully considers the influential factors for the evaluation of brand extension for products targeting young customers. This study analyzed the three important characteristics of consumers by employing a new and proposed nomological network to assess the brand extension and its strategies. First, the brand extension was directly regressed with the need for uniqueness and with innovativeness. After observing the significance of the regressed model, the model was finally analyzed with the intervening variable of need for variety. Six hypotheses were developed, and the proposed theoretical model was assessed through structural equation modeling (SEM) with the help of SmartPLS. Data was collected from 331 university students of southern Punjab, Pakistan. It was found that all three personal characteristics of young consumers (need for uniqueness, innovativeness, and need for variety) are highly significant with the evaluation of brand evaluation. The proposed model explained more than $30 \%$ variation in the observed phenomenon. It was observed that the need for variety partially mediates the relationship between the need for uniqueness, innovativeness, and brand extension. As per the results of this study, it was found that the variety of products matters a lot for young customers so, marketers must consider the variation in the products while extending their product line. Theoretically, this study contributed and enhanced the nomological network of brand extension for young consumers.

Cite as: Orangzab, Sajjad, M., Zulfiqar, M. U., Chani, M. I., Tariq, B., \& Hussain, R. I. (2021). Influential Factors of Brand Extension among University Students: Case for Pakistan. Marketing and Management of Innovations, 2, 278-292. http://doi.org/10.21272/mmi.2021.2-23

278 
Orangzab, M., Sajjad, M. U., Zulfiqar, M. I., Chani, B., Tariq, R. l., Hussain. Influential Factors of Brand Extension among University Students: Case for Pakistan

Practically, the study would help the decision-makers understand the preferences of the young generation to devise the new strategies of brand extension.

Keywords: brand extension, innovativeness, brand variety, brand uniqueness, structural equation modeling, factors of brand extension, young consumers.

Introduction. Many companies introduce new products as a part of their business growth strategies. Companies introduce a brand extension to benefit from brand knowledge they have already developed in the existing marketplace (Aaker and Keller, 1990; Milberg et al., 1997). Marketing costs and failure rates are reduced when a company introduces a new product using an existing brand name (Husnain et al., 2020; Keller, 1993; Milewicz and Herbig, 1994). Brand extensions benefit the parent brand by strengthening the existing dealings (Aaker and Joachimsthaler, 2000) and brand positioning modification (Park et al., 1986). Anderson (1983) and Morrin (1999) provided «associative network theory», according to this theory, the brand image could be considered as a psychological proposal shaped through a set of connections of linking associations (Morrin, 1999). The brand extension could strengthen the existing linkages of associations or create new associations.

According to Latter et al. (2010), the intention of a consumer's need for uniqueness (NFU) has a significant effect on a purchase decision. It is normal to conceptualize that diverse individuals demonstrate different amounts of need for uniqueness (NFU). Besides, that could significantly impact their purchase choices (Snyder and Fromkin, 1977). In fashion, styles and new trends are continually varying individuals who contain a high need for uniqueness be apt to accept faster innovative products and brands (Bertrandias and Goldsmith, 2006). Innovative consumers are more concerned about the latest products (Steenkamp et al., 1999). In previous research, people are interested in variety (Ratner et al., 1999; Read and Loewenstein, 1995; Simonson, 1990). By consuming similar items, the utility of those would be the decline, known as satiation. For managing satiation, consumers often seek variety (Inman, 2001; McAlister and Pessemier, 1982). Previous studies on brand extension mainly focus on brands such as the impact of existing brand image, image fit, category fit, the experience of extension on brand extension (Martinez and De Chernatony, 2004; Martínez and Pina, 2010; Volckner and Sattler, 2006). According to Broniarczyk and Alba (1994), when links or features of parent brand are highly relevant, consumers possibly assess brand extension extra positively. The status feature plays an important role. Besides, a decent brand reputation helps identify brand extension and extend the brand to an extensive range of product types (Park et al., 1991). Permitting to Del Rio et al. (2001) study, the roles linked to social identity have a substantial influence on the adoption of brand extensions. Hutton (1997) has identified a strong link between brand credibility and the willingness of the customer to pay high prices and embrace brand expansion. Along with the brand-related factors, the consumer-related factors or characteristics may also influence the assessment of brand extension, but very few studies focus on this connection. Consequently, the primary objective of this reading is to define the effect of consumer-related factors on the brand extension assessment. The present research is organized into four sections. The next section reassesses literature to validate the study's theoretical model and the relationship instituted in the hypotheses. The third section presents the methodology applied to validate the theoretical model. In turn, the fourth section contains results. The final section focused on the conclusion and managerial assumption.

Literature Review. Brand extension is a suitable approach for improving brand positioning (Park et al., 1986), reinforcing brand equity associations, improving parent brand image (Morgan and Rego, 2009). In the case of foremost brands that benefit from admirable repute and many people purchase them, the brand extension would be considered by customers more positively (Aaker, 2004). Brand-associated values could also be diluted by extension by creating associations that are different or puzzling from the existing associations (John et al., 1998; Tauber, 1988). The model proposed in the present study assists in comprehending the stimulus of customer characteristics on the brand extension evaluation. For this 
cause, the model comprises the important customer characteristic that could greatly impact brand extension. The need for uniqueness is obtained from the theory of uniqueness developed by Snyder and Fromkin (1977). Tian et al. (2001) characterize the need for the individuality of consumers (NFU) as the trait of monitoring discrepancies compared to others through the purchase, use, and disposal of consumer products to build and improve one's self-image and social image. Need for uniqueness (NFU) comprises of three extents: 1) creative choice counter-conformity; 2) unpopular choice counter-conformity; and 3) avoidance of similarity (Tian et al., 2001). In creative choice, counter-conformity consumers desire to differentiate themselves from most other people by using unique, novel, or new brands that other people consider good because they still want to be accepted by society by fulfiling the social norms (Tian et al., 2001). Consumers who want to differentiate themselves from others by using unusual products they more likely to display variety seeking and new product adoption behavior (McAlister and Pessemier, 1982). According to Kron (1983), creative consumer choices involve some risk. Under an unpopular choice counter-conformity, consumers want to differentiate themselves from other people. In this case, they use products or brands that are not fulfilling the group customs and create a danger of dissatisfaction from the community because they could not find active approaches to differentiate themselves, which is acceptable to their community (Tian et al., 2001). According to Heckert (1989), unpopular consumer decisions in an earlier phase might attain community acknowledgment in the future and positively differentiate the user as a pioneer. For that consumer who seeks uniqueness, negative comments from others would be ineffective. They ignore negative comments from others (Simonson, 1990). In avoidance of similarity, consumers want to differentiate themselves from others by avoiding common brands and stop spending on brands considered popular to avoid similarities with others (Tian et al., 2001). Consumers fulfill their need for uniqueness by purchasing those products that others cannot afford (Sun et al., 2017). Lang and Armstrong (2018) found a positive influence of the need for uniqueness on collective consumption. People are willing to swap the products with others who need unique characteristics because they prefer variety.

According to Snyder and Fromkin (1977), items containing uniqueness and limited proceed are considered special when there is a need for uniqueness. Unsatisfactory self-evaluation creates the need for uniqueness (Fromkin, 1970). Those individuals with a high need for uniqueness could amend their choice policy compared to others (Drolet, 2002). People in certain cultures attached positive meaning with variety-seeking because they attached positive meaning with uniqueness. According to commodity theory, the scarcity of anything enhances its value (Lynn, 1991). The purchase of a unique, novel, different or new brand gives a consumer a unique feeling. Perceived uniqueness increases the value of the brand. Individuals that need uniqueness prefer rare items to distinguish themself from others (Fromkin, 1970). According to the same author, innovativeness could be the consequence of the need for uniqueness. Firstly, because the need for uniqueness could be satisfied by innovativeness easily, and secondly, for innovative purchasing, independence in judgment is necessary, which is included in the need for uniqueness. Burns and Brady (1992) empirically validated the positive connection between the need for uniqueness (NFU) and the innovative product possession. Therefore, it is expected that consumers who need uniqueness are more innovative, demand more variety, and positively evaluate the brand extension. It brings to the subsequent hypotheses:

$\mathrm{H} 1$ : The need for uniqueness is significantly linked with the need for variety.

$\mathrm{H} 2$ : The need for uniqueness is significantly linked with innovativeness.

$\mathrm{H} 3$ : The need for uniqueness is significantly related to the brand extension.

One assumption that is considered by whole literature on brand extension is that the risk connected through buying novel products reduced by brand extension of a known brand (Smith and Park, 1992), and consumer risk aversion is revealed by consumer innovativeness. The consumers' propensity to consider the latest ideas and buy new items is represented by consumer innovativeness (Midgley and Dowling, 
1978; Roehrich, 2004). «Innovativeness is a desire to purchase diverse and fresh brands and produces rather than stay on with past market trends» (Steenkamp and Baumgartner, 1992).

Innovative people are extra open to risk (Hem et al., 2003). Perceived quality and purchase intention are higher for tangible products Volckner and Sattler (2006) and new services Siu and Mou (2005) favor innovative consumers. Far extensions are appealing for highly innovative individuals, then late adopters Xie (2008) tried those commodities away from the company's central business. Consumer innovativeness plays an important role in new product adoption intentions (Li et al., 2015). Personality characteristics like consumer innovativeness lead to enhanced extension manner for good Volckner and Sattler (2006) and service extensions (Hem et al., 2003; Siu and Mou, 2005). Therefore, innovative consumers are expected to be extra open to new products, require more variety, and positively evaluate the brand extension. Thus, the following hypotheses were formulated.

$\mathrm{H} 4$ : Consumer innovativeness is positively related to the need for variety.

H5: Consumer innovativeness has a significant impact on the assessment of brand extension.

With a specific end goal to establish an imprint about others to unique them besides exciting, somewhat uninteresting or closed-minded and to fulfill the inner requirements, buyers frequently look for variety (Ariely and Levav, 2000; Raju, 1980; Ratner and Kahn, 2002). While different purchasers perform persistent behavior, look for consistency and display stable tendencies towards the brand that performs well in the earlier period (Jones and Sasser, 1995; Oliver, 1999) and create an emotional association with the organization and the brand (Johnson et al., 2006). Hoyer and Ridgway (1984) characterize diversity as «the search for a different and fresh stimulation», and it is seen in numerous forms, including the action of brand switching (Steenkamp and Baumgartner, 1992). Optimal stimulation level (OSL) has been used in literature to assess and describe the action of finding variation (Orth, 2005; Orth and Bourrain, 2005; Raju, 1980). OSL applies to the response of a person to environmental stimuli. Berlyne (1957) explained that this stimulus motivates the internal driver to avoid boredom by seeking change and novelty (McAlister and Pessemier, 1982). Due to satiation or boredom, the stimulation level records as low (diminishing lower than the optimal level of stimulation). In this situation, exploration or variety seeking would be commenced to optimize stimulation to the desired level. In decision making, variety seeking plays an important role (Niininen et al., 2004). Seeking variety motivates investigative inclinations such as innovating and brand exchange (Price and Ridgway, 1983; Raju, 1980; Trijp et al., 1996; Wood and Swait, 2002). Previous studies represent the number of factors that motivate consumers to consider variety in their choices over time. For instance, consumers consider variety because they might have attractive features or become familiar with new options (Kahn, 1995; Maqsood and Soomro, 2021). According to McAlister and Pessemier (1982), consumers consider variety in their preferences to avoid or diminish the satiation resulting from repetitive consumption of a particular thing. According to Fishbach et al. (2011), those who want to motivate novel products should focus on satiation features. Consumers may consider variety to achieve stimulation (Raju, 1980). Consumers consider repetition related to uniformity and represent closed-mindedness, while variety-seeking indicates open-mindedness and avoids satiation (Ratner and Kahn, 2002). The concept of boredom represents that decisions related to consumption should be transformed over time because consumers become satiated or exhausted with something that might have initially been preferred. The diverse set of objects allocates people to represent their interests rather than boring (Kim and Drolet, 2003; Ratner and Kahn, 2002). Indecisiveness is allied with amplified diversitypursuing comportment (Jeong and Drolet, 2016). Variety seeking is capable of being happening due to features outer of mindful understanding. The number of situational cues could trigger the variety-seeking behavior and probably affect how people clarify their selections. Through brand extension, the existing brand could introduce different brands that could help to reduce satiation from existing customers. Therefore, it is expected that those consumers who need variety more positively evaluate brand extension.

H6: The need for variety is positively related to the evaluation of brand extension. 


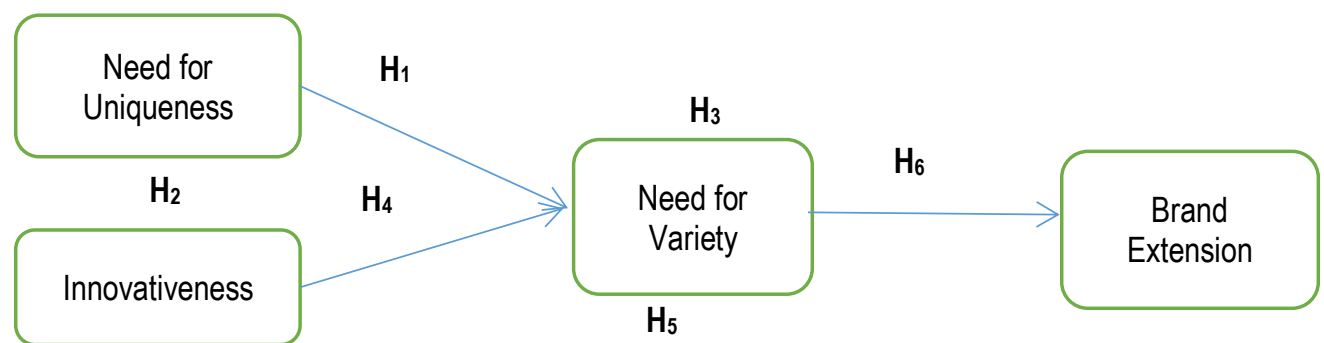

Figure 1. Conceptual framework representing the effect of customer characteristics on brand extension evaluation

Sources: developed by the authors.

Methodology and research methods. The primary data was collected through self-administered questionnaires consists of a five-point Likert scale which contains a close-ended pattern of queries/questions from respondents. On the questionnaire's second page, respondents were requested to suppose their favorite brand would introduce the extension. After that, the questions then evaluate the attitudes of the respondents towards the extension. Information about the attributes and benefits of the extension was not provided to avoid bias that could affect the study objective.

The target population consists of students of Southern Punjab who are enrolled in higher education institutes of both public and private sectors. Southern Punjab is the less developed part of the Punjab province. The government is paying attention to providing quality education to the students of South Punjab and tens to establishing new Universities in that part of the province for that purpose. 10 public and 1 private University, while 13 public and 5 private Universities sub-campuses provide education in Southern Punjab (Higher Education Commission Pakistan). This study involves the South because it is considered to be a backward area, less focused on research, and researchers also have affiliation with this area. The reason for selecting the student is that youngsters were more inclined towards the brand than others. The estimated population size was 96945 , and the selected sample size was 331 . According to the sample size table provided by (Sekaran and Bougie, 2016), 300 sample is suitable for population up to 0.1 million. Having 10 responses against every parameter is valid and vital to decide a suitable sample size ( Hair et al., 2007; McQuitty, 2004).

According to this method, 240 responses are appropriate because the questionnaire contains 24 questions, but 331 responses were taken. In this study, the sample was selected randomly, and data were collected from all major Universities of Southern Punjab of Pakistan. The respondents were approached by the researchers in different Universities on different days and different times throughout January and February 2018. Measures for the need for uniqueness are taken from (Ruvio, 2008) for consumer innovativeness from (Roehrich, 2004), for the need for variety from (Michaelidou and Dibb, 2009), while for brand extension measures are taken from (Martínez and Pina, 2010). For meeting the desired objective of the study, Statistical software like Smart-PLS and SPSS are utilized.

Results. The sample profile is providing below in Table 1. It represents that the Male respondents (183) remain grater than the Females defendants (148). The defendants' age represents that the bulk of respondent's 61.3 percent, are between the age of 19 to 22. Out of 331 respondents, 302 respondents belong to public sector universities or institutes, while 29 respondents are getting an education from private sector universities or institutes. 
Orangzab, M., Sajjad, M. U., Zulfiqar, M. I., Chani, B., Tariq, R. l., Hussain. Influential Factors of Brand Extension among University Students: Case for Pakistan

Table 1. Sample Profile of the Respondents

\begin{tabular}{llll}
\hline Factors & & Valid No & Percentage (\%) \\
\hline \multirow{3}{*}{ Gender } & Male & 183 & 55.3 \\
& Female & 148 & 44.7 \\
& Up to 18 & 27 & 8.2 \\
Age & $19-22$ & 203 & 61.3 \\
& $23-26$ & 97 & 29.3 \\
& $27-30$ & 4 & 1.2 \\
University/Institute & Public & 302 & 91.2 \\
\hline
\end{tabular}

Sources: developed by the authors.

Table 2 below provides the descriptive statistics containing the values of lowest, supreme, mean, standard deviation, skewness, and kurtosis of all the main constructs used in this study. Five-point Likert scale use in this study. That's why values swing from 1 to 5 . The mean standards of entire constructs are bigger than (3), representing and providing the respondents' neutral response. Goodboy and Kline (2017) provided a range for skewness and kurtosis when the data distribution is considered normal. According to this study, data is considered approximately normal when the skewness and kurtosis values are among the range of -3 to +3 . In table 2 , skewness and kurtosis values are within the acceptable range, which means that data is approximately normally distributed.

Table 2. Descriptive Statistics

\begin{tabular}{ccccccc}
\hline Variables & Min & Max & Mean & Standard Deviation & skewness & Kurtosis \\
\hline Need for Uniqueness & 1.39 & 5.00 & 3.2867 & .70197 & -.011 & -.159 \\
Innovativeness & 1.33 & 5.00 & 3.4859 & .89035 & -.445 & -.476 \\
Need for Variety & 1.00 & 5.00 & 3.7523 & .87613 & -.607 & -.079 \\
Brand Extension & 1.00 & 5.00 & 3.8238 & .85211 & -.649 & .047 \\
\hline
\end{tabular}

Sources: developed by the authors.

Cronbach's Alpha values are taken to test the precision of the tests. Table 3 provides the Cronbach's Alpha values. Hedonic innovativeness and social innovativeness are the two main dimensions of innovativeness through unpopular choice, creative choice, and avoidance of similarity are three main dimensions of need for uniqueness. All the values are in an acceptable range. Perry Hinton et al. (2004) judged in a revision that Alpha( $a)$ values $(a>6)$ or $(a=6)$ a satisfactory level.

Table3. Reliability analysis

\begin{tabular}{cc}
\hline Variables & Cronbach's Alpha \\
\hline Hedonic Innovativeness & .768 \\
Social Innovativeness & .705 \\
Creative Choice & .627 \\
Unpopular Choice & .680 \\
Avoidance of Similarity & .729 \\
Need for Variety & .725 \\
Brand Extension & .699 \\
\hline
\end{tabular}

Sources: developed by the authors.

Discriminant validity (DV) was measured in this study through factor loading values and by contrasting the square root $\sqrt{ }$, values of the Average Variance Extracted (AVE) with the connection of that construct with other constructs used in the study. If the correlation of that construct with another construct is less 
Orangzab, M., Sajjad, M. U., Zulfiqar, M. l., Chani, B., Tariq, R. l., Hussain. Influential Factors of Brand Extension among University Students: Case for Pakistan

than the square root $\sqrt{ } \mathrm{x}$ of $\mathrm{AVE}$, then that construct has adequate discriminant validity (Chin, 1998; Fornell and Larcker, 1981). According to Straub et al. (2004), loadings for all the construct items should be greater than 0.40. Values in Table 4 represent that the loadings of all the items of the constructs used in this research are greater than 0.40 . The bold values in table 5 indicate the $\sqrt{x}$ (square root) of AVE; these bold standards have a greater association of that paradigm with other constructs of the study which satisfy the criteria of discriminant validity.

Table 4. Loadings and AVE

\begin{tabular}{lllc}
\hline \multicolumn{1}{c}{ Constructs } & \multicolumn{1}{c}{ Item } & \multicolumn{1}{c}{ Loadings } & $\begin{array}{c}\text { Average Variance } \\
\text { Extracted (AVE) }\end{array}$ \\
\hline Need for Uniqueness & Avoidance of Similarity & 0.659 & 0.540 \\
& Creative Choice & 0.935 & \\
Unnopular Choice & 0.560 & 0.74 \\
& Hedonic Innovativeness & 0.892 & \multirow{2}{*}{ Innovativeness } \\
Need for Variety & Social Innovativeness & 0.827 & \\
& N_F_V_18 & 0.819 & \\
& N_F_V_19 & 0.714 & \\
Brand Extension & N_F_V_20 & 0.660 & 0.611 \\
& N_F_V_21 & 0.734 & \\
& B_Ext222 & 0.867 & \\
& B_E_23 & 0.723 & \\
\hline
\end{tabular}

Sources: developed by the authors.

Table 5 below represent the correlation between need for uniqueness, innovativeness, need for variety and brand extension. The results show that need for uniqueness has positive correlation with innovativeness $(r=.571)$ and $P$-value is less than 0.05 that's why this correlation is significant. Need for uniqueness also has positive significant link with need for variety (NFV) $(F=.439, p=.000)$ plus brand extension ( $f=.396, p=.000$ ) respectively. Innovativeness has moderate positive relationship with need for variety $(r=.416)$ and brand extension $(r=.420)$, correlation is noteworthy as $P$-value is less than the given standard which is 0.05 . Need for variety also has moderate significant positive correlation with brand extension $(r=.550, p=.000)$.

Table 5. Discriminant validity and correlation of main constructs

\begin{tabular}{|c|c|c|c|c|c|}
\hline Variables & & $\begin{array}{l}\text { Need for } \\
\text { Uniqueness }\end{array}$ & Innovativeness & Need for Variety & $\begin{array}{c}\text { Brand } \\
\text { Extension }\end{array}$ \\
\hline \multirow{4}{*}{$\begin{array}{l}\text { Need for } \\
\text { Uniqueness }\end{array}$} & Pearson Correlation & 0.735 & $.571^{\star \star}$ & $.439^{\star \star}$ & $.396^{\star *}$ \\
\hline & Sig. (2-tailed) & & .000 & .000 & .000 \\
\hline & $\mathrm{N}$ & 331 & 331 & 331 & 331 \\
\hline & Pearson Correlation & $.571^{* *}$ & 0.860 & $.416^{\star *}$ & $.420^{* *}$ \\
\hline \multirow[t]{3}{*}{ Innovativeness } & Sig. (2-tailed) & .000 & & .000 & .000 \\
\hline & $\mathrm{N}$ & 331 & 331 & 331 & 331 \\
\hline & Pearson Correlation & $.439^{* *}$ & $.416^{* *}$ & 0.734 & $.550^{* *}$ \\
\hline \multirow[t]{3}{*}{ Need for Variety } & Sig. (2-tailed) & .000 & .000 & & .000 \\
\hline & $\mathrm{N}$ & 331 & 331 & 331 & 331 \\
\hline & Pearson Correlation & $.396^{* *}$ & $.420^{* *}$ & $.550^{* *}$ & 0.782 \\
\hline \multirow[t]{2}{*}{ Brand Extension } & Sig. (2-tailed) & .000 & .000 & .000 & \\
\hline & $\mathrm{N}$ & 331 & 331 & 331 & 331 \\
\hline
\end{tabular}

Correlation is significant at the 0.01 level (2-tailed).

Sources: developed by the authors. 
Orangzab, M., Sajjad, M. U., Zulfiqar, M. l., Chani, B., Tariq, R. l., Hussain. Influential Factors of Brand Extension among University Students: Case for Pakistan

For the VIF adequate cut-o,ff which is (<5) with a tolerance of >0.20 (Hair et al., 2011; Henseler, 2018; Sarstedt et al., 2017).

Table 6. Collinearity statistics

\begin{tabular}{ccc}
\hline \multirow{2}{*}{ Predictors } & \multicolumn{2}{c}{ Collinearity Statistics } \\
\cline { 2 - 3 } Need for Uniqueness & Tolerance & VIF \\
\cline { 2 - 3 } Innovativeness & .674 & 1.484 \\
\end{tabular}

*Dependent variable: Need for Variety

Sources: developed by the authors.

In Table 6, the need for variety is taken as the dependent variable, while in Table 7 - brand extension. All the tolerance values are $>0.20$, and VIF values are $<5$, representing no collinearity issue.

Table 7. Collinearity statistics

\begin{tabular}{ccc}
\hline \multirow{2}{*}{ Predictors } & \multicolumn{2}{c}{ Collinearity Statistics } \\
\cline { 2 - 3 } & Tolerance & VIF \\
\cline { 2 - 3 } Need for Uniqueness & .625 & 1.600 \\
Innovativeness & .640 & 1.562 \\
Need for Variety & .767 & 1.305 \\
\hline
\end{tabular}

Dependent variable: Brand Extension

Sources: developed by the authors.

The structural model of Rendering to Hair et al. (2012) offers details about interaction in the presumed sample model. The structural model offers a path coefficient in regression analysis that is the same as the structured beta coefficient (Agarwal and Karahanna, 2000). T-values are used to assess the importance of the interaction between the study's objects. In turn, it is used to make judgments about proposed hypotheses. The structural model of the $s$ is described in figure 1.

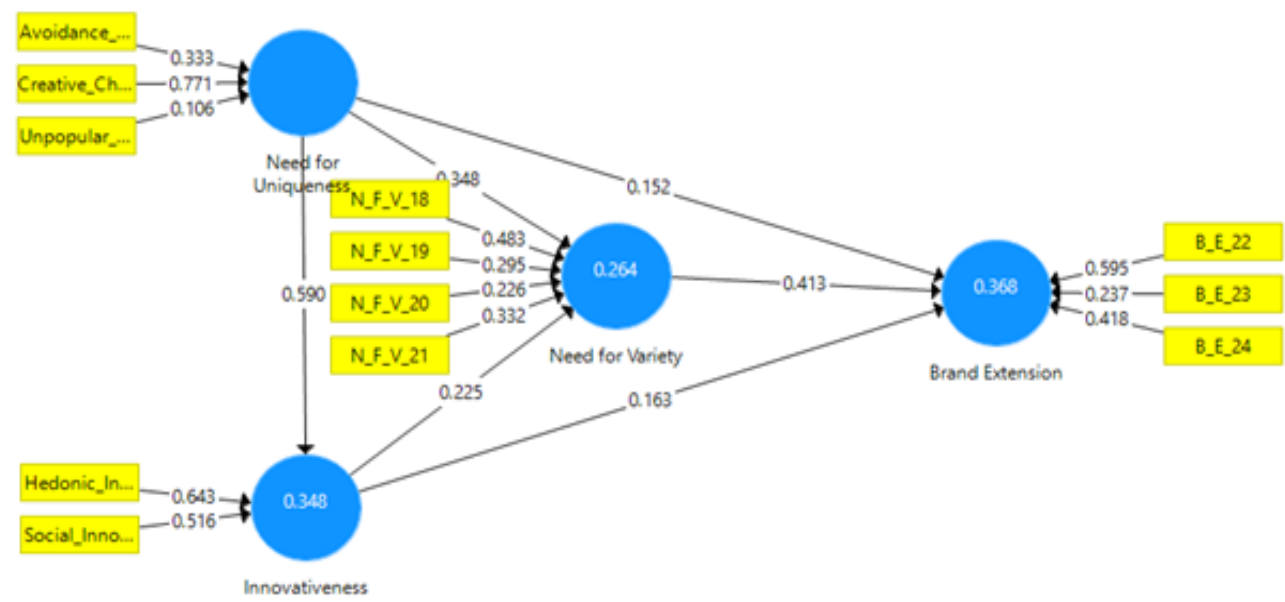

Sources: developed by the authors

Figure 1. Structural model 
Orangzab, M., Sajjad, M. U., Zulfiqar, M. I., Chani, B., Tariq, R. l., Hussain. Influential Factors of Brand Extension among University Students: Case for Pakistan

Table 8 below delivers all values of path coefficient, $t$-values, and $p$-values. All the ( $p$-values) are less than (.05), and ( $t$-values) are greater than (1.96). In light of these all, hypotheses of current studies are supported well.

Table 8. Results of hypotheses testing

\begin{tabular}{cccccr}
\hline Hypothesis & Relations & $\begin{array}{c}\text { Parameter } \\
\text { Estimator }\end{array}$ & t-value & p-value & Status \\
\hline H1 & Need for Uniqueness $\rightarrow$ Need for Variety & 0.348 & 4.987 & 0.000 & Supported \\
H2 & Need for Uniqueness $\rightarrow$ Innovativeness & 0.590 & 13.764 & 0.000 & Supported \\
H3 & Need for Uniqueness $\rightarrow$ Brand Extension & 0.152 & 2.383 & 0.018 & Supported \\
H4 & Innovativeness $\rightarrow$ Need for Variety & 0.225 & 3.029 & 0.023 & Supported \\
H5 & Innovativeness $\rightarrow$ Brand Extension & 0.163 & 2.283 & 0.003 & Supported \\
H6 & Need for Variety $\rightarrow$ Brand Extension & 0.413 & 6.262 & 0.000 & Supported \\
\hline
\end{tabular}

Sources: developed by the authors.

According to McAlister and Pessemier (1982), consumers who need uniqueness and want to differentiate themselves from others are more inclined towards new product adoption and display varietyseeking behavior. The need for uniqueness is positively correlated with possessing a new product (Burns and Brady, 1992). The findings of this study are similar to the results of these researchers. The need for uniqueness has a positive impact on the need for variety and brand extension acceptance. Innovativeness could be the consequence of the need for uniqueness (Fromkin, 1970). This study identified that those consumers who need uniqueness also represent innovativeness. Consumer innovativeness is one of the essential factors of brand extension acceptance (Hem et al., 2003; Volckner \& Sattler, 2006). This study also supports it as innovativeness is one of the antecedents for brand extension acceptance, but its impact is not strong. Eren-Erdogmus et al. (2018) found that innovativeness does not affect the acceptance of extension. When a brand name is still the parent brand name, innovative consumers perceive low or no new products.

Table 9. Mediation with the need for variety

\begin{tabular}{cccccc}
\hline & Direct Impact & \multicolumn{3}{c}{ Indirect Impact (with a mediator) } \\
\hline Path Coefficient & P-Value & R Square & Path Coefficient & P-Value & R Square \\
0.448 & 0.000 & 0.201 & 0.231 & 0.000 & 0.346 \\
\hline
\end{tabular}

Sources: developed by the authors.

Table 9 represents that need for uniqueness has a substantial impression on brand extension as $p<$ .05 , and the value of $R^{2}$ is 0.201 . By containing the need for variety as an intermediary, the impression of the need for uniqueness on brand extension (BE) is compact. At the same time, the value of $R^{2}$ is amplified as (0.346), although this impression relic is momentous. Consequently, it was accomplished need for variety to intervene in the relationship between the need for uniqueness and brand extension.

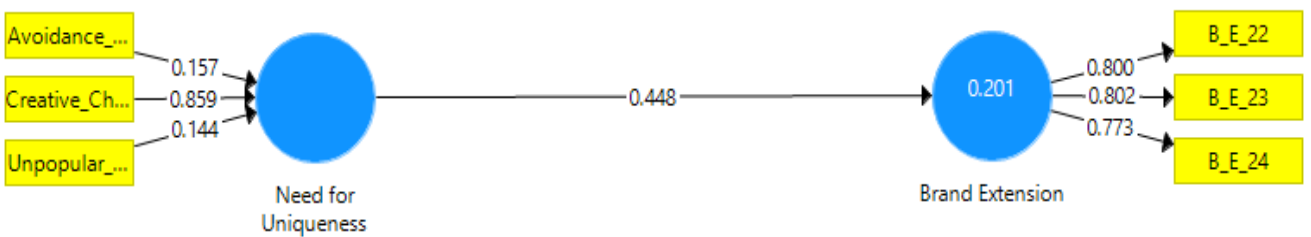

Sources: developed by the authors

Figure 2. Direct impact 


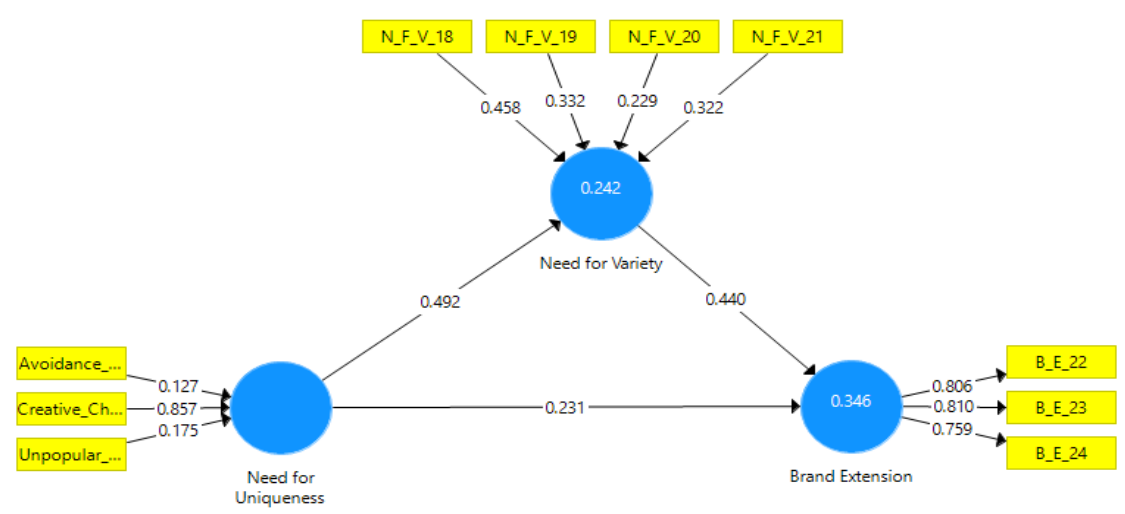

Figure 3. Indirect impact

Sources: developed by the authors.

Table 10 represents that the need for uniqueness significantly impacts the need for variety $(p<.05)$ and $R^{2}$ value (0.243). By counting innovativeness as a mediator, the need for uniqueness impact on the need for variety is abridged, the $R^{2}$ value is marginally improved (0.261), whereas the impact remains substantial. Hence, we accomplish that innovativeness to some extent mediates the affiliation between the need for uniqueness and the need for variety.

Table 10. Mediation with Innovativeness

\begin{tabular}{cccccc}
\hline & Direct Impact & & \multicolumn{3}{c}{ Indirect Impact (with a mediator) } \\
\hline Path Coefficient & P-Value & R Square & Path Coefficient & P-Value & R Square \\
0.493 & 0.000 & 0.243 & 0.337 & 0.000 & 0.261 \\
\hline
\end{tabular}

Sources: developed by the authors.

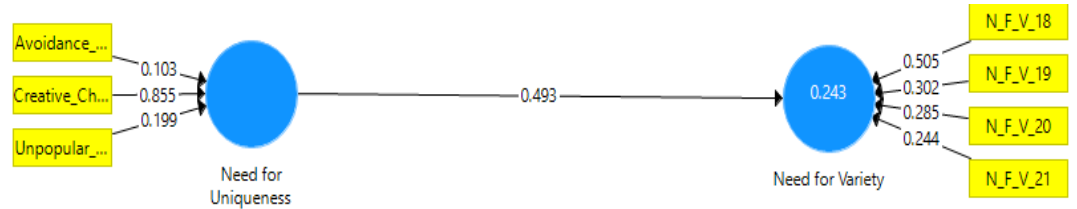

Figure 4. Direct impact for the need for variety

Sources: developed by the authors.

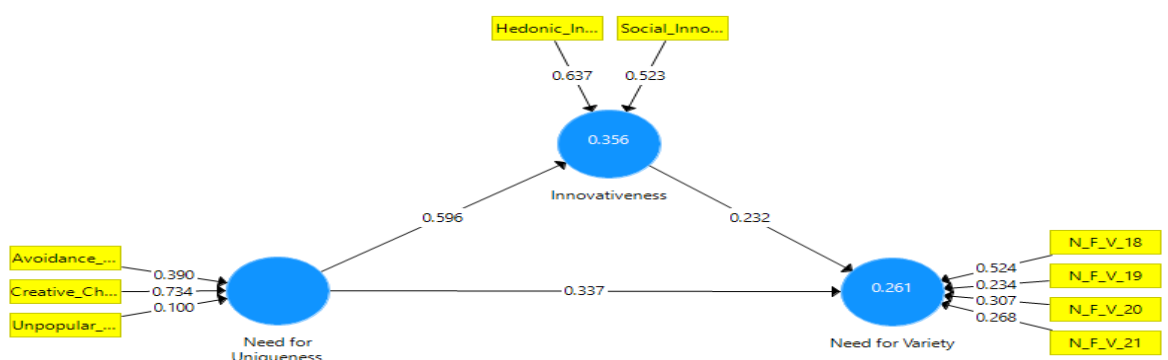

Figure 5. Indirect impact with the need for variety

Sources: developed by the authors. 

University Students: Case for Pakistan

Table 11 below shows that creativity has a significant effect on the extension of the company, and the $R^{2}$ is 0.187 . The influence of novelty on brand extension is minimized by using the need for diversity as a mediator. The $R^{2}$ value increased (0.352), although this impact remains important. Therefore, the study infers that the need for variety partly mediates the relationship between creativity and brand expansion.

Table 11. Mediation with the need for variety

\begin{tabular}{cccccc}
\hline & \multicolumn{3}{c}{ Direct Impact } & \multicolumn{3}{c}{ Indirect Impact (with a mediator) } \\
\hline Path Coefficient & P-Value & R Square & Path Coefficient & P-Value & R Square \\
0.433 & 0.000 & 0.187 & 0.231 & 0.000 & 0.352 \\
\hline
\end{tabular}

Sources: developed by the authors.

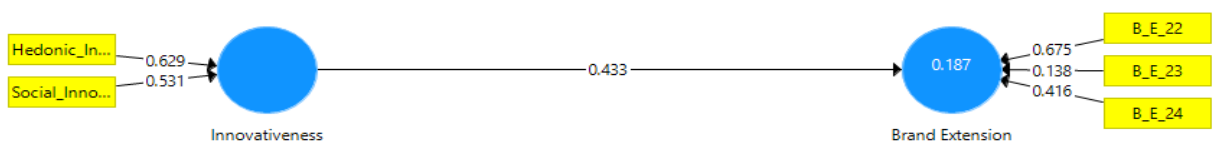

Figure 6. Direct Impact for Brand Extension

Sources: developed by the authors.

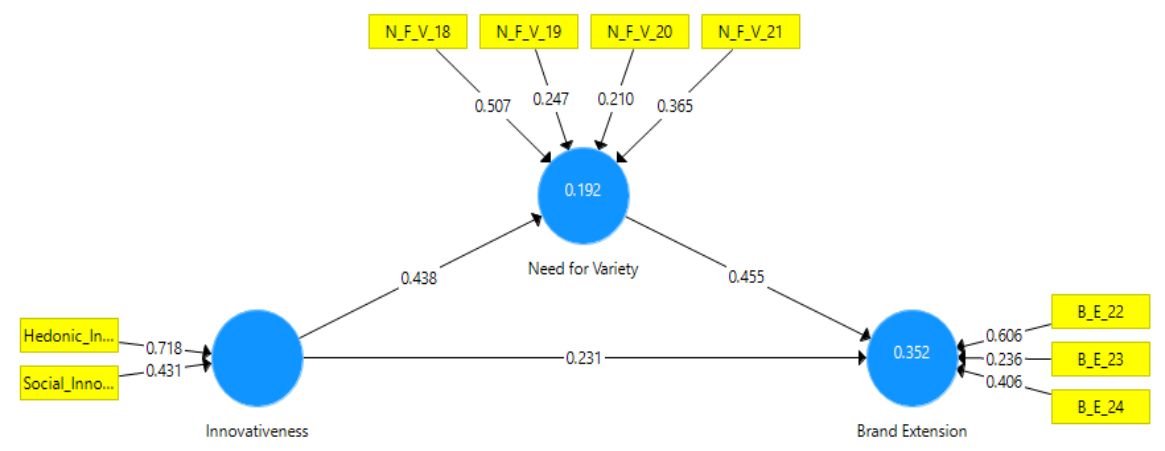

Figure 7. Indirect impact for brand extension

Sources: developed by the authors.

Conclusion. The brand expansion helps organizations from multiple points of view, for example, limiting the danger of presenting another product, diminishing the cost of expansion, and expanding the consideration of the new product by buyers. The foremost aim of this examination was to propose a hypothetical model of brand extension. This research analyses the effect of consumer characteristics on the evaluation of brand extension by utilizing three consumer characteristics relevant to the evaluation of brand extension. A significant dedication of this investigation was to address this gap in the literature by building up a model for particular consumer attributes for the accomplishment of brand extensions. By determining a part for specific variable affiliations, this examination constructs a unique model. This examination is the first to feature the consumer attributes that impact brand extension as an arrangement for brand extension. Brand extensions are useful in expanding customer trustworthiness by considering these characteristics at the top of the priority list amid the extension process. The findings showed that consumer characteristics diverse in a range of examinations that impact brand extension accomplishment by exploring the literature on brand extensions. In this study, three important consumer characteristics (need for uniqueness, innovativeness, \& need for variety) relevant to the brand extension are studied. It 

University Students: Case for Pakistan

was established that all characteristics have a considerable positive influence on evaluating brand extension. Under considering the results from the present study, all hypotheses were accepted. The findings showed that variety has a greater influence on the acceptance of brand extension among all three consumer characteristics. We also found that the need for variety partially mediates the relationship between uniqueness, innovativeness, and acceptance of brand extension relationships. Those consumers easily accept brand extension who are more concerned about variety. The examination and testing of the proposed model would offer professionals and managers a more profound comprehension of future brand extensions. This study's outcomes help managers include bits of knowledge into the possibilities and risks of brand extensions. This investigation was piloted among students from various universities in the Southern Region of Pakistan. It could lack the generalizability of the results to the entire county. Therefore, future investigations could be simulated this investigation of brand extension in other areas of the county. Rather than considering mediators, the need for variety and innovativeness could be considered as moderating variables. A comparative study amongst males and females could be conducted by measuring the choice of both genders about the brand extension. Furthermore, studies with more potential consumer personality-related characteristics such as impulse decision making or sensation-seeking could be performed for brand extension success.

Author Contributions: conceptualization, O. and M. S.; methodology, M. U. Z. and B. T.; software, M. I. C.; validation, R. I. H.; formal analysis, M. I. C. and O.; investigation, R. I. H. and M. U. Z., resources, O. B. T.; data curation, M. I. C. and O.; writing - original draft preparation, M. U. Z. and O.; writing, review and editing, M. S. and M. I. C.; upervision, 0.

Funding: This research has received no external funding.

\section{References}

Aaker, D. A. (2004). Leveraging the corporate brand. California management review, 46(3), 6-18. [Google Scholar] [CrossRef] Aaker, D. A., \& Joachimsthaler, E. (2000). The brand relationship spectrum: The key to the brand architecture challenge. California management review, 42(4), 8-23. [Google Scholar] [CrossRef]

Aaker, D. A., \& Keller, K. L. (1990). Consumer evaluations of brand extensions. Journal of marketing, 54(1), 27-41. [Google Scholar] [CrossRef]

Agarwal, R., \& Karahanna, E. (2000). Time flies when you're having fun: Cognitive absorption and beliefs about information technology usage. MIS quarterly, 665-694. [Google Scholar] [CrossRef]

Anderson, J. R. (1983). A spreading activation theory of memory. Journal of verbal learning and verbal behavior, 22(3), 261295. [Google Scholar] [CrossRef]

Ariely, D., \& Levav, J. (2000). Sequential choice in group settings: Taking the road less traveled and less enjoyed. Journal of consumer Research, 27(3), 279-290. [Google Scholar] [CrossRef]

Berlyne, D. E. (1957). Conflict and information-theory variables as determinants of human perceptual curiosity. Journal of experimental psychology, 53(6), 399. [Google Scholar] [CrossRef]

Bertrandias, L., \& Goldsmith, R. E. (2006). Some psychological motivations for fashion opinion leadership and fashion opinion seeking 25. Journal of Fashion Marketing and Management, 10, 1. [Google Scholar] [CrossRef]

Broniarczyk, S. M., \& Alba, J. W. (1994). The importance of the brand in brand extension. Journal of marketing research, 31(2), 214-228. [Google Scholar] [CrossRef]

Burns, D. J., \& Brady, J. (1992). A cross-cultural comparison of the need for uniqueness in Malaysia and the United States. The Journal of Social Psychology, 132(4), 487-495. [Google Scholar]

Chin, W. W. (1998). The partial least squares approach to structural equation modeling. Modern methods for business research, 295(2), 295-336. [Google Scholar]

del Rio, A. B., Vazquez, R., \& Iglesias, V. (2001). The effects of brand associations on consumer response. The Journal of Consumer Marketing, 18(4/5), 410. [Google Scholar] [CrossRef]

Drolet, A. (2002). Inherent Rule Variability in Consumer Choice: Changing Rules for Change's Sake. Journal of Consumer Research, 29(3), 293-305. [Google Scholar] [CrossRef]

Eren-Erdogmus, I., Akgun, I., \& Arda, E. (2018). Drivers of successful luxury fashion brand extensions: cases of complement and transfer extensions. Journal of fashion marketing and management: an international journal, 22(4), 476-493. [Google Scholar] [CrossRef] 
Orangzab, M., Sajjad, M. U., Zulfiqar, M. I., Chani, B., Tariq, R. l., Hussain. Influential Factors of Brand Extension among University Students: Case for Pakistan

Fishbach, A., Ratner, R. K., \& Zhang, Y. (2011). Inherently loyal or easily bored?: Nonconscious activation of consistency versus variety-seeking behavior. Journal of Consumer Psychology, 21(1), 38-48. [Google Scholar] [CrossRef]

Fornell, C., \& Larcker, D. F. (1981). Evaluating structural equation models with unobservable variables and measurement error. Journal of marketing research, 18(1), 39-50. [Google Scholar] [CrossRef]

Fromkin, H. L. (1970). Effects of experimentally aroused feelings of undistinctiveness upon valuation of scarce and novel experiences. Journal of personality and social psychology, 16(3), 521. [Google Scholar] [CrossRef]

Goodboy, A. K., \& Kline, R. B. (2017). Statistical and practical concerns with published communication research featuring structural equation modeling. Communication Research Reports, 34(1), 68-77. [Google Scholar] [CrossRef]

Hair, J. F., Money, A. H., Samouel, P., \& Page, M. (2007). Research methods for business. Education+ Training, 49(4), 336337. [Google Scholar] [CrossRef]

Hair, J. F., Ringle, C. M., \& Sarstedt, M. (2011). PLS-SEM: Indeed a silver bullet. Journal of Marketing theory and Practice, 19(2), 139-152. [Google Scholar] [CrossRef]

Hair, J. F., Sarstedt, M., Ringle, C. M., \& Mena, J. A. (2012). An assessment of the use of partial least squares structural equation modeling in marketing research. Journal of the academy of marketing science, 40(3), 414-433. [Google Scholar] [CrossRef] Heckert, D. M. (1989). The relativity of positive deviance: The case of the French Impressionists. Deviant Behavior, 10(2), 131144. [Google Scholar] [CrossRef]

Hem, L. E., De Chernatony, L., \& Iversen, N. M. (2003). Factors influencing successful brand extensions. Journal of Marketing Management, 19(7-8), 781-806. [Google Scholar] [CrossRef] Henseler, J. (2018). Partial least squares path modeling: Quo vadis?. Quality \& Quantity, 52(1), 1-8. [Google Scholar] [CrossRef]

Hoyer, W. D., \& Ridgway, N. M. (1984). Variety seeking as an explanation for exploratory purchase behavior: A theoretical model. ACR North American Advances, 11(1), 114-119. [Google Scholar] Husnain, M., Syed, F., Akhtar, W., \& Usman, M. (2020). Effects of Brand Hate on Brand Equity: The Role of Corporate Social Irresponsibility and Similar Competitor Offer. Marketing and Management of Innovations, 3, 75-86. [Google Scholar] [CrossRef] Hutton, J. G. (1997). A study of brand equity in an organizational-buying context. Journal of Product \& Brand Management, 6(6). [Google Scholar] [CrossRef]

Inman, J. J. (2001). The role of sensory-specific satiety in attribute-level variety seeking. Journal of Consumer research, 28(1) 105-120. [Google Scholar] [CrossRef]

Jeong, H. G., \& Drolet, A. (2016). Variety-seeking as an emotional coping strategy for chronically indecisive consumers. Marketing Letters, 27(1), 55-62. [Google Scholar] [CrossRef]

John, D. R., Loken, B., \& Joiner, C. (1998). The negative impact of extensions: can flagship products be diluted?. Journal of Marketing, 62(1), 19-32. [Google Scholar] [CrossRef] Johnson, M. D., Herrmann, A., \& Huber, F. (2006). The evolution of loyalty intentions. Journal of marketing, 70(2), 122-132. [Google Scholar] [CrossRef]

Jones, T. O., \& Sasser, W. E. (1995). Why satisfied customers defect. Harvard business review, 73(6), 88. [Google Scholar] Kahn, B. E. (1995). Consumer variety-seeking among goods and services: An integrative review. Journal of retailing and consumer services, 2(3), 139-148. [Google Scholar] [CrossRef]

Keller, K. L. (1993). Conceptualizing, measuring, and managing customer-based brand equity. Journal of marketing, 57(1), 1 22. [Google Scholar] [CrossRef]

Kim, H. S., \& Drolet, A. (2003). Choice and self-expression: A cultural analysis of variety-seeking. Journal of personality and social psychology, 85(2), 373. [Google Scholar] [CrossRef]

Kron, J. (1983). The semiotics of home decor. Home-Psych: The Social Psychology of Home and Decoration. New York: Crown, 72-82. [Google Scholar]

Lang, C., \& Armstrong, C. M. J. (2018). Collaborative consumption: The influence of fashion leadership, need for uniqueness, and materialism on female consumers' adoption of clothing renting and swapping. Sustainable Production and Consumption, 13, 3747. [Google Scholar] [CrossRef]

Latter, C., Phau, I., \& Marchegiani, C. (2010). The roles of consumers need for uniqueness and status consumption in haute couture luxury brands. Journal of Global Fashion Marketing, 1(4), 206-214. [Google Scholar] [CrossRef]

Li, G., Zhang, R., \& Wang, C. (2015). The role of product originality, usefulness and motivated consumer innovativeness in new product adoption intentions. Journal of Product Innovation Management, 32(2), 214-223. [Google Scholar] [CrossRef] Lynn, M. (1991). Scarcity effects on value: A quantitative review of the commodity theory literature. Psychology \& Marketing, 8(1), 43-57. [Google Scholar] [CrossRef]

Maqsood, S. M., \& Soomro, Y. A. (2021). Gray-market and its Impacts on Brand Image: Case for Retail Perfume Industry. Marketing and Management of Innovations, 2021(1), 124-134. [Google Scholar] [CrossRef]

Martinez, E., \& De Chernatony, L. (2004). The effect of brand extension strategies upon brand image. Journal of consumer marketing, 21(1), 39-50. [Google Scholar] [CrossRef]

Martínez, E., \& Pina, J. M. (2010). Consumer responses to brand extensions: a comprehensive model. European Journal of Marketing, 44(8), 1182-1205. [Google Scholar] [CrossRef] 
Orangzab, M., Sajjad, M. U., Zulfiqar, M. I., Chani, B., Tariq, R. l., Hussain. Influential Factors of Brand Extension among University Students: Case for Pakistan

McAlister, L., \& Pessemier, E. (1982). Variety seeking behavior: An interdisciplinary review. Journal of Consumer research, 9(3), 311-322. [Google Scholar] [CrossRef]

McQuitty, S. (2004). Statistical power and structural equation models in business research. Journal of Business Research, 57(2), 175-183. [Google Scholar] [CrossRef]

Michaelidou, N., \& Dibb, S. (2009). Brand switching in clothing: the role of variety-seeking drive and product category-level characteristics. International Journal of Consumer Studies, 33(3), 322-326. [Google Scholar] [CrossRef]

Midgley, D. F., \& Dowling, G. R. (1978). Innovativeness: The concept and its measurement. Journal of consumer research, 4(4), 229-242. [Google Scholar] [CrossRef]

Milberg, S. J., Park, C. W., \& McCarthy, M. S. (1997). Managing negative feedback effects associated with brand extensions: The impact of alternative branding strategies. Journal of Consumer Psychology, 6(2), 119-140. [Google Scholar] [CrossRef] Milewicz, J., \& Herbig, P. (1994). Evaluating the brand extension decision using a model of reputation building. Journal of Product \& Brand Management, 3(1), 39-47. [Google Scholar] [CrossRef] Morgan, N. A., \& Rego, L. L. (2009). Brand portfolio strategy and firm performance. Journal of Marketing, 73(1), 59-74. [Google Scholar] [CrossRef]

Morrin, M. (1999). The impact of brand extensions on parent brand memory structures and retrieval processes. Journal of Marketing Research, 36(4), 517-525. [Google Scholar] [CrossRef]

Nininen, O., Szivas, E., \& Riley, M. (2004). Destination loyalty and repeat behaviour: An application of optimum stimulation measurement. International Journal of Tourism Research, 6(6), 439-447. [Google Scholar] [CrossRef]

Oliver, R. L. (1999). Whence Consumer Loyalty?. Journal of marketing: A quarterly publication of the american marketing association, 63(4), 33-44. [Google Scholar] [CrossRef]

Orth, U. (2005). Consumer personality and other factors in situational brand choice variation. Journal of Brand Management, 13(2), 115-133. [Google Scholar] [CrossRef]

Orth, U. R., \& Bourrain, A. (2005). Optimum stimulation level theory and the differential impact of olfactory stimuli on consumer exploratory tendencies. ACR North American Advances. [Google Scholar]

Park, C. W., Jaworski, B. J., \& Maclnnis, D. J. (1986). Strategic brand concept-image management. Journal of marketing, 50(4), 135-145. [Google Scholar] [CrossRef]

Park, C. W., Milberg, S., \& Lawson, R. (1991). Evaluation of brand extensions: The role of product feature similarity and brand concept consistency. Journal of consumer research, 18(2), 185-193. [Google Scholar] [CrossRef] Perry Hinton, D., Hinton, P. R., McMurray, I., \& Brownlow, C. (2004). SPSS explained: Routledge. [Google Scholar]

Price, L. L., \& Ridgway, N. M. (1983). Development of a scale to measure use innovativeness. ACR North American Advances, 83(10), 679-684. [Google Scholar]

Raju, P. S. (1980). Optimum stimulation level: Its relationship to personality, demographics, and exploratory behavior. Journal of consumer research, 7(3), 272-282. [Google Scholar] [CrossRef]

Ratner, R. K., \& Kahn, B. E. (2002). The impact of private versus public consumption on variety-seeking behavior. Journal of Consumer Research, 29(2), 246-257. [Google Scholar] [CrossRef]

Ratner, R. K., Kahn, B. E., \& Kahneman, D. (1999). Choosing less-preferred experiences for the sake of variety. Journal of consumer research, 26(1), 1-15. [Google Scholar] [CrossRef]

Read, D., \& Loewenstein, G. (1995). Diversification bias: Explaining the discrepancy in variety seeking between combined and separated choices. Journal of Experimental Psychology: Applied, 1(1), 34. [Google Scholar] [CrossRef]

Roehrich, G. (2004). Consumer innovativeness: Concepts and measurements. Journal of business research, 57(6), 671-677. [Google Scholar] [CrossRef]

Ruvio, A. (2008). Unique like everybody else? The dual role of consumers' need for uniqueness. Psychology \& Marketing, 25(5), 444-464. [Google Scholar] [CrossRef]

Sarstedt, M., Ringle, C. M., \& Hair, J. F. (2017). Partial least squares structural equation modeling. Handbook of marke research, 26(1), 1-40. [Google Scholar] [CrossRef]

Sekaran, U., \& Bougie, R. (2016). Research methods for business: A skill building approach. John Wiley \& Sons. [Google Scholar]

Simonson, I. (1990). The effect of purchase quantity and timing on variety-seeking behavior. Journal of Marketing research, 27(2), 150-162. [Google Scholar] [CrossRef

Siu, N. Y. M., \& Mou, J. C. W. (2005). Measuring service quality in internet banking: the case of Hong Kong. Journal of International Consumer Marketing, 17(4), 99-116. [Google Scholar] [CrossRef]

Smith, D. C., \& Park, C. W. (1992). The effects of brand extensions on market share and advertising efficiency. Journal of marketing research, 29(3), 296-313. [Google Scholar] [CrossRef]

Snyder, C. R., \& Fromkin, H. L. (1977). Abnormality as a positive characteristic: The development and validation of a scale measuring need for uniqueness. Journal of Abnormal Psychology, 86(5), 518. [Google Scholar] [CrossRef

Steenkamp, J. B. E., \& Baumgartner, H. (1992). The role of optimum stimulation level in exploratory consumer behavior. Journa of consumer research, 19(3), 434-448. [Google Scholar] [CrossRef]

Steenkamp, J. B. E., Ter Hofstede, F., \& Wedel, M. (1999). A cross-national investigation into the individual and national cultural antecedents of consumer innovativeness. Journal of marketing, 63(2), 55-69. [Google Scholar] [CrossRef] 
Orangzab, M., Sajjad, M. U., Zulfiqar, M. I., Chani, B., Tariq, R. l., Hussain. Influential Factors of Brand Extension among University Students: Case for Pakistan

Straub, D., Boudreau, M. C., \& Gefen, D. (2004). Validation guidelines for IS positivist research. Communications of the Association for Information systems, 13(1), 24. [Google Scholar]

Sun, G., Chen, J., \& Li, J. (2017). Need for uniqueness as a mediator of the relationship between face consciousness and status consumption in China. International Journal of Psychology, 52(5), 349-353. [Google Scholar] [Google Scholar]

Tauber, E. M. (1988). Brand leverage: strategy for growth in a cost-control world. Journal of Advertising Research, 28(4), 2630. [Google Scholar]

Tian, K. T., Bearden, W. O., \& Hunter, G. L. (2001). Consumers' need for uniqueness: Scale development and validation. Journal of consumer research, 28(1), 50-66. [Google Scholar] [CrossRef]

Trijp, H. C. V., Hoyer, W. D., \& Inman, J. J. (1996). Why switch? product category-level explanations for true variety-seeking behavior. Journal of marketing research, 33(3), 281-292. [Google Scholar] [CrossRef]

Volckner, F., \& Sattler, H. (2006). Drivers of brand extension success. Journal of marketing, 70(2), 18-34. [Google Scholar [CrossRef]

Wood, S. L., \& Swait, J. (2002). Psychological indicators of innovation adoption: Cross-classification based on need for cognition and need for change. Journal of Consumer Psychology, 12(1), 1-13. [Google Scholar] [CrossRef]

Xie, Y. H. (2008). Consumer innovativeness and consumer acceptance of brand extensions. Journal of Product \& Brand Management, 17(4), 235-243. [Google Scholar] [CrossRef]

Орангзаб, Ph.D, Ісламабадський університет COMSATS, Пакистан

Мухаммед Саджад, Ph.D, Ісламабадський університет COMSATS, Пакистан

Мухаммад Умайр Зульфікар, Ph.D, Ісламабадський університет COMSATS, Пакистан

Мухаммед Ірфан Чані, Ph.D, Ісламабадський університет COMSATS, Пакистан

Білал Тарік, Ph.D, Ісламабадський університет COMSATS, Пакистан

Рай Імтіаз Хуссейн, Університет Окари, Пакистан

Промоція бренда університету: кейс для Пакистану

Ефективність промоції бренда є одним із ключових фракторів успішності запуску нових продуктів. А Авторами зазначено що ефективна стратегія промоції бренда забезпечує отримання додаткових конкурентних переваг. Метою статті є аналіз факторів ефективної промоції бренда університету серед молоді. Оцінювання ефективності промоції бренда проведено на основі номологічної мережі. Модель промоції бренду побудовано з урахуванням таких ффакторів: унікальність, інноваційність, потреба у різноманітності. У рамках дослідження висунуто шість гіпотез та запропоновано теоретичну модель оцінювання ефективності промоції бренда за допомогою методу моделювання структурних рівнянь (SEM). Практичну реалізацію дослідження здійснено з використанням інструментарію програмного забезпечення SmartPLS. Емпіричне дослідження проведено на основі панельних даних, сформованих на основі опитування 331 студента Університету Південного Пенджабу (Пакистан). За результатами дослідження встановлено, що три характеристики ефективності промоції бренда (унікальність, інноваційність та потреба у різноманітності) $є$ статистично значущими при оцінюванні бренда. Запропонована модель пояснюе більш ніж 30\%-варіацію досліджуваного явища. За результатами встановлено, що потреба в різноманітності частково опосередковує взаємозв'язок між потребою в унікальності, інноваційності та промоції бренду. Отримані результати засвідчили, що фрактор «різноманітність» суттєво впливає прийняття рішень молоддю. Таким чином, університетам необхідно приділяти особливу увагу різноманітності освітніх послуг. Теоретичною цінністю дослідження є удосконалення номологічної мережі промоції бренда, орієнтуючись на молодь. Результати дослідження сприяють кращому розумінню потреб молоді та можуть бути корисними особам, які приймають рішення, при розробленні маркетингових стратегій промоціі бренда університету.

Ключові слова: розширення бренда, інноваційність, різноманітність бренда, унікальність бренда, моделювання структурних рівнянь, фактори промоції бренда, споживач. 